\title{
1
}

\section{The theoretical setting}

\section{Why theorise?}

Forty years of theorising European integration have produced a situation where one might expect that little remains to be said. This is not an attempt to escape the intellectual responsibility of developing a greater understanding of the forces that constantly form and reform the regional system. It is only to state that the theory of such a polysemous concept as 'integration' appears to have reached a high plateau in its Western European context. Not that theorists of European integration should start looking for new regional experiments of comparable analytical potential. Rather, the idea is that the new challenges facing the study of regional integration in Europe (concerning both its theoretical boundaries and operational dynamics) do not take place in a theoretical vacuum: they are an extension, if not a refinement, of older ones. The task remains to discover a reliable integration theory as the basis for the future of he European Union (EU) and offer a convincing response to the challenges of large-scale polity formation.

Legitimately, however, one wonders whether Puchala's cynical prophecy that integration theory will amount to 'a rather long but not very prominent footnote in the intellectual history of twentieth century social science' will prove as accurate as the author would have us believe. ${ }^{1}$ A first response might be that theory matters, whether or not its conceptual findings and qualifications are to be evenly appreciated by scholars and practitioners alike. For familiarity with theory helps to test our analytical tools and appreciate their relevance in real-life situations: According to Taylor: 'Each theory . . . leads to unique insights which are valid starting points for the purpose of comparison and evaluation.' ${ }^{2} \mathrm{Or}$, as alternatively put by Keohane and Hoffmann: 'Attempts to avoid theory ... not only miss interesting questions but rely on a framework for analysis that remains unexamined precisely because it is implicit.' ${ }^{3}$ True, a great deal has still 
to be accomplished. But as long as theory-building is at the top of the academic agenda, there is good ground for thinking that important possibilities are deemed to be explored.

But what might constitute such 'possibilities'? How are they to be explored? What is the appropriate methodological line to that end? To start with, substantive progress in the field requires the transcendence of descriptive approaches about, on the one hand, the form and functions of the integrative process and, on the other, the resolution of fundamental conceptual problems confronting a discipline which has become subject to diverse interpretation. This requires, in Church's words, 'structured ways of understanding changing patterns of interaction, ${ }^{4}$ free from the inherently fragmented boundaries of micro-analysis: to project a macroscopic view of the Union based on systematic conceptual explanation. To that end, 'We need to be aware of the conceptions we use since they determine our perception of things. ${ }^{5}$ This methodological pathway to the study of European integration allows higher access to reality or, alternatively, offers the infrastructure from which 'a hierarchy of realities' might emerge. ${ }^{6}$

The analytical validity of these presuppositions is further justified when trying to establish a link between continuity and change within a system of multinational shared rule; when attempting to identify the common values of distinct polities and the prospects for the emergence of new ones; when aiming at throwing some additional light on the dialectical and increasingly symbiotic union between a highly interactive society of independent nations and new sources of political authority; or even when engaging in a process of investigating the allegedly 'part-formed' and/or sui generis physiognomy of a composite 'union' comprising distinct culturally defined and politically organised units, where the dynamics of intrastate policy-making intermesh with those of large-scale polityformation with enormous complexity, producing a new type of collective entity characterised by interlocking structures of political authority: a transnational polity, which lacks a single locus of authoritative decision-making.

But even more difficult is to evaluate critically an ever-expanding corpus of literature dealing with such a rich kaleidoscope of relations. And all this, while trying to make sense of a hidden political agenda concerning the future of the European state system itself and the viability of democratic arrangements within and across pre-established borders. Whatever the lessons stemming from the process of bringing together a number of democratic governments under the organisational logic of a larger management system, the work at hand will have made a contribution if it offers an opportunity to communicate the major concerns underlying the evolutionary nature of European governance and its functionally structured subsystems. Such a task represents, above all, a pragmatic challenge, confronting, on the one hand, the transformation of international behaviour and, on the other, the assertion of a new core set of values and principles of what might best be described as 'political co-determination': the forging of new co-operative arrangements for jointly managing the internal and external affairs of the nascent European polity. The perennial question to ask 
here is whether such a composite polity will strike a balance between its becoming the main locus of collective, binding decision-making for the constituent governments and the dominant focus of popular political identification.

To start with, there is a case to be made why existing theories of integration, even when taken in a complementary manner, fall short of capturing the dominant character of the relationship between the region (Union) and the subunits (states/substate system/citizens). A first attempt to answer this question is that Mitrany's functionalism, Haas' revised version of it (what was conveniently labelled as 'neofunctionalism') and the various federalist-inspired approaches to European integration, ranging from the American model of 'dual federalism' to the 'co-operative federalism' of the German political system, find it equally difficult to reconcile two apparently mutually exclusive principles: the preservation of high levels of segmental autonomy within a nascent, yet politically and constitutionally uncrystallised, system of mutual governance. That is, to capture the dynamics of two complementary objectives: strengthening the political viability of separate constitutional orders through the institutionalisation of joint sovereignty and with it the practice of political co-determination. The intellectual problem associated with such an endeavour is rooted in the different treatments and perceptions of 'general concepts' such as sovereignty, autonomy and interdependence, to mention only a few. Both normative and narrative interpretations of the integrative project, purporting to identify the logic of a distinct form of regionalism and its implications for the participating state and societies, often tend to overemphasise either the importance of the central institutions or, conversely, the role of national governments in setting the integrative agenda and then acting authoritatively upon it. This 'battle of theories' has produced zero-sum notions of transnational bargaining, coupled with unjustified confidence in how the system actually works and towards what it is developing. The 'elephant', however, to recall Puchala's colourful description, is not easy to manipulate in theoretical terms: it often turns into a 'chameleon', adjusting itself to the actual requirements of the day. ${ }^{7}$

\section{Defining the Union}

The conceptual problems mentioned above are further compounded by the fact that, on the basis of existing typologies, the Union still remains, almost by definition, an unsolved puzzle: a 'half-way house' between the worlds of 'federal state' and 'federal union of states.' Although the Union is often taken to imply something more than the mere aggregate of its constituent parts, political authority has not yet moved towards a new regional centre. In this view, the Union is neither an international organisation as conventionally understood, nor is it becoming an ordinary state possessing a monopoly of law-making and law-enforcing powers. But equally puzzling remains the nature of its legal structure. For some, the Union rests upon a series of international treaty-based rules, while others prefer to speak of an incipient constitutional system driven by aspirations akin to those involved in traditional state-building. From an integration 
theory perspective, although the larger polity exceeds the Deutschian notion of a 'pluralistic security-community', it has failed to meet either the sociopsychological conditions of the older functionalist school or those related to the formation of a neofunctionalist-inspired European 'political community'.

Profoundly uncrystallised in its political superstructure, the Union remains an integrative venture whose final destination is yet to become discernible. Attributes such as 'partial polity' and 'part-formed political system' clearly demonstrate the lack of confident scholarly assertion," while rendering the whole enterprise 'a challenge to the continuing separation of international relations from political science. ${ }^{10}$ But even without taking into account the series of neologisms invented over time to capture the distinctive properties that make up its governance structures, the intermeshing of federal principles, confederal structures and consociational processes (see Chapter 2) renders its institutional setting far from comprehensible. Simply to argue, however, that the Union is a polity suigeneris and should thus be examined in terms of new conceptual paradigms or ad hoc theoretical interpretations, or even a combination of both, runs the danger of complying with undisciplined and often ill-founded formulations, while perpetuating its present stance in the grey, 'in-between' area of 'normal interstate' and 'normal intrastate relations': the two extreme poles of an analytical continuum on which political systems are conventionally located. ${ }^{11}$ Herein lies perhaps the greatest intellectual challenge facing the contemporary student of European integration: to fill the existing gap between state-centric theory and federalist-driven approaches and develop a more profound understanding of what the Union actually is. ${ }^{12}$

To give a brief account of the complexity surrounding the issue of defining the regional system: Wallace notes that what has now been created by the constituent governments is 'a constitutional system which has some state attributes, but which most - or all - of its constituent governments do not wish to develop into a state, even while expecting it to deliver outcomes which are hard to envisage outside the framework of an entity which we would recognise as a (federal) state. ${ }^{13} \mathrm{He}$ adds: 'The retreat from a federal objective for the European Community, while retaining a constitutional agenda which implied the need for a federal state-framework, has left a shadowy area at the center of EC construction. ${ }^{14}$ In this context, Sbragia asserts that it is perhaps more useful to think of the Community as 'an ongoing experiment in fashioning a new structure of governance, one that accepts a great deal of cultural diversity as well as incorporating politics based on the state-society model and politics based on relations between governments. ${ }^{15}$ Behind this statement lies the concept of symbiosis between the collectivity and the segments, adding credence to those employing co-operative federalism as a model for explaining current integrative arrangements, as well as to Taylor's understanding of the constitutional implications of the symbiotic process for the changing conditions of sovereign statehood in contemporary Europe. ${ }^{16}$

In attempting to explain the origins of political unions, McKay has put the issue thus: 'What we have witnessed in Europe ... is a movement towards 
federation which has indigenous rather than external roots, over which there is near unanimity among elites and which has already produced real results in terms of the delineation of power between national and supra-national (or federal) authorities. ${ }^{17}$ Moravcsik, on his part, by developing a theory of 'liberal intergovernmentalism' (see Chapter 2), describes the Union as a regime that makes interstate bargaining more efficient, while enhancing the autonomy of national leaders; ${ }^{18}$ a definition close to Puchala's understanding of the larger polity as a multilevel 'system of managed interdependence. ${ }^{19}$ But while Wallace accepts that the Union is 'more than an international regime but less than a fully-developed political system', questioning whether it can be seen as 'a political "community" in the widest sense, ${ }^{20}$ Webb takes it to be 'a partially-integrated policy-making system at the regional level, ${ }^{21}$ thus making Cameron's 'institutionalised intergovernmentalism' sound like a relatively specific analogy. ${ }^{22}$

Writing on the inappropriateness of classical statist, purely intergovernmental, and traditional federal forms of political organisation, Keohane and Hoffmann have captured the evolving European reality as 'an elaborate set of networks, closely linked in some ways, partially decomposed in others, whose results depend on the political style in the ascendant at the moment. ${ }^{23}$ But perhaps one of the most 'progressive' classifications has been Scharpf's conception of the then European Community (EC) as a 'joint-decision system', where the pathology of public policy-making is conditioned by a 'systemic tendency towards sub-optimal substantive solutions', exemplifying the notion of a 'jointdecision trap' or politikverflechtungfalle. ${ }^{24}$ Embracing Wallace's dictum that the Community system is 'stuck between sovereignty and integration', while recognising that the effectiveness and implementation of common policies are greatly influenced by what Taylor had earlier called the 'interdependence trap', Scharpf argues that Europe 'seems to have become just that "middle ground between co-operation among nations and the breaking of a new one" which Stanley Hoffmann thought impossible. ${ }^{25}$ Although this statement contradicts the view that progress towards the formation of a European demos - conceived in civic rather than ethnocultural terms - should not be seen as a prelude to the emergence of a larger 'political nation', it adds something to the current debate. Other terms to be found in the acquis académique as means of conceptualising the larger entity include 'proto-federation', 'confederance', 'concordance system', 'quasi-state', 'Staatenverbund, 'consortio', 'condominio', 'regulatory state', 'regional regime', 'mixed commonwealth', 'managed Gesellschaft', 'quasi-state', 'sympolity', 'federated republic', 'market polity', 'international state', 'confederal consociation', 'multilevel governance' and so on. If anything, the above definitional accounts suggest that the question of what the Union 'actually' is has yet to be sorted out.

Given the various conceptual and analytical difficulties in reaching an authoritative statement on the political physiognomy of the present-day Union, we suggest that, instead of placing undue emphasis on the peculiarities of its constitutive properties, it is perhaps more profitable to examine those aspects of 
its internal political organisation which can be paralleled, with a greater or lesser degree of accuracy, with already familiar forms of polity and/or models of governance. The underlying premise here is that a new theoretical thesis will not only have to take into account pre-existing classifications, but will also have to use them constructively so as to substantiate its findings both theoretically and empirically. As Groom has observed: 'There must be acknowledgment of the old Europe, but also a realisation that in building a new one, there are many original aspects that do not fit easily into the customary conceptual frameworks of integration theory. ${ }^{26}$

The general thesis put forward in this book is that we are currently witnessing the reversal of the Mitranian logic of international integration: instead of 'form follows function, ${ }^{27}$ it is increasingly the case that the structural properties of the larger management system dictate the pace and range of joint integrative schemes. Thus an additional concern has become manifest: the extension of the 'scope' (range) and 'level' (depth) of European integration do not necessarily coincide. Since the coming into force of the SEA in February 1987 and the TEU in November 1993, there is evidence to suggest that both the functional scope (new policy arenas) and territorial scale (new members) of the integrative process may well be extended, if not at the expense of the level of integration (ways of management), without either altering the locus of sovereignty or having any significant impact on the way in which the central institutions exercise political authority. The extension of QMV by these treaty revisions, as well as by the AMT in May 1999 and the more recent Treaty of Nice (signed in February 2001), on largely non-conflict-prone areas, helps to illustrate this point. But let us now turn to the way in which this ever-demanding exercise of EU theory-building has evolved over time.

\section{Theorising integration}

As already suggested, there are various ways of examining an inherently interdisciplinary object of study; arguably, as many as the constitutive bodies of theory which allegedly compose it. The process of European integration, revolving around the three-pillar structure of the Union - a structure which managed to survive any ambition to communitarise in any substantive terms its two intergovernmental components at the June 1997 and December 2000 Amsterdam and Nice Summits, respectively - is a good case in point. For since the early days of the process, students of European integration have applied a variety of methods and approaches in order to develop a more profound understanding of what the European 'body politic' looked like at the many different stages of its political and, in the wider sense of the term, constitutional, evolution. And yet, despite the many promising theoretical departures over the years, arguably only a few concrete theoretical arrivals have been achieved.

Different traditions of international relations theory, ranging from pluralist paradigms of interstate behaviour to (neo)realist interpretations of state-centric preferences and power, coupled with a plethora of approaches flowing from the 
domain of comparative politics 'proper' - in turn, seeking to link the domestic and international arenas of European governance - seem to have exhausted the analytical spectrum within which the study of European integration can bear fruits. More recently, however, a preference has emerged for the latter analytical pathway (the term 'comparativists' capturing this scholarly trend), although intergovernmentalism, or even modified schemes of co-operative interstate behaviour (at both treaty-formation and daily policy-making levels), have by and large survived the tides of supranationalism and institutional centralisation.

Doubtless, the initial supranationalist schemes were of considerable integrative potential, dominating the domestic policy arena of the Community during the formative years of the regional process. This was a period when Hallstein's Presidency of the newly founded Commission aimed at projecting a new structure of managing the affairs of the Community's nascent regime. Later, however, it was followed by a more balanced relationship between the Community's supranational/expansionist ambitions and intergovernmental realities. This was the beginning of what has been termed, after the 1966 Luxembourg Accords, the 'Second Europe': a transition stage leading to the 1969 Hague Summit, in turn hailed as the first significant relance of integration. The third integrative stage came about only a few years later, with the formal institutionalisation of the European Council at the 1974 Paris Summit. This top political institution was expected to provide the leadership needed to move the Community towards higher levels of integration, acting at the same time as a protective mechanism for sensitive (and often non-negotiable) national interests. Such a development signalled the inception of what was later to be termed as the 'Third Europe': a qualitatively different phase from the pre-1974 one, this time characterised by a more favourable version of intergovernmentalism as a method of promoting integration. The end result of this stage - itself a largely 'compromised structure' of the previous two - projected a symbiotic arrangement between national and European political (and even polity) dynamics.

The many different phases of European integration and the subsequent theoretical approaches devoted to their explanation point to the assumption that the formation of a European polity, as distinct from the making of a new regional superstate (a superordinate form of government beyond the nation-state), or for that matter from the construction of a purely confederal structure (a loosely institutionalised society of sovereign states), resembles an asymmetrical and often analytically incongruent synthesis of academic (sub)disciplines. Yet the rationale of studying the integrative phenomenon from the perspective of various, and often contending, schools of thought seems to be as relevant today as it was during the formative debate between functionalists and federalists (although this was a far less complicated one). But how are we to appreciate the enormous diversity embedded in the various theoretical approaches to the study of European integration in general, and its multifarious arenas of collective policy- and decision-making in particular? A first answer is to look at each particular theory of integration separately, placing at the same time its conceptual 
findings and analytical insights in a wider comparative context. Here, undoubtedly, functionalism emerges as an appropriate point of departure.

\section{Core theories of integration}

\section{Functionalism}

In general terms, functionalism purports to explain why collective action in specific, functionally linked areas of co-operation is a more attractive option than unilateral state action: group involvement in peaceful problem-solving schemes, supported by the necessary technical expertise, emanates as a real option. Nationalism and international anarchy are treated as the sources of the fragmentation of the world community into rival groups, obstructing the creation of a 'working peace system'. International community-building is the functionalist remedy to these problems, centred on the resolution of basic welfare needs which transcend territorial considerations. Mitrany's understanding of 'the integrative dynamic', Taylor notes, 'is the learning process of citizens who are gradually drawn into the co-operative ethos created by functionally specific international institutions devoted to the satisfaction of real welfare needs.' ${ }^{28}$

This organic process is furthered by what may be described as 'management committee government', reflecting Mitrany's distrust of traditional assembly controls over complex policy-making. Guided by the quest to watch closely for the 'relation of things', Mitrany argued the case for replacing old-style, non-specialist assemblies with new forms of representation and ways of obtaining public control, such as 'functional' assemblies composed of experts whose technical knowledge would guarantee greater and better efficiency in supervising governmental actions. In The Functional Theory of Politics, he reiterates that 'no one would share in power who did not share in responsibility' and that 'the functional structure could be made a union of peoples ... directly concerned in any specific function, by giving them functional representation. ${ }^{29}$ Mitrany's underlying rationale was that in acquiring formal representative status, [pressure groups] also assume a corresponding democratic responsibility. ${ }^{30}$ No doubt, however, this form of democracy, labelled by Mitrany himself as 'working democracy' (as opposed to 'voting democracy') is seen by those who perceive the institution of Parliament as the focal point of accountability as a hindrance to established notions of representative and responsible government.

The functionalist conception of 'union' is part of an evolutionary process of achieving functionally specific objectives, and not of a deterministic situation leading, immediately or necessarily, towards a federal state or even a state-like entity. Like other gradualist theories, the end product of the integration process is left deliberately vague (although some form of larger constitutional framework is not dismissed outright). One reason for this is that, according to Mitrany, 'form follows function' in that the actual needs of the integrative system will determine its structural properties. Although it would be false to 
assume that functionalist theory perceives federalism as an uncontrolled homogenising force eroding national diversity and/or identity, it maintains that it is in the interests of the integration process itself to proceed in an incremental, piecemeal fashion. Hence the idea of a modest 'step-by-step' approach as opposed to a federalist-inspired 'head-on' approach to European unity for fear that a federal surrender of sovereignty would be too big a sacrifice for national governments on the altar of their unification.

The key concept of the functionalist method is identified in the perception of a common interest among the various actors involved in the integration process, as well as a propensity to non-coercive means of problem-solving. This was judged to be vitally important for the European region to develop the necessary institutional machinery to produce common policies and decisions, not least due to its recent turbulent history. Thus the pursuit of common tasks was linked from the outset to the creation of common institutions possessing a responsibility of their own, albeit limited in scope. As Kitzinger has pointed out, the main difference between functionalists and federalists was that, whereas the former were preoccupied with defining the 'general interest' first, and then finding common answers to common problems, the latter sought joint action as a means for obtaining more efficient central institutions. ${ }^{31}$ As a result, the functionalists sought 'to set up only that minimum of political institutions that was indispensable in order to direct the common action that was most urgently required.32 Supranationalism, as applied in a specific regional context producing a larger-scale territorial authority, is perceived as a potential source of replicating nationalist sentiments at a level beyond the nation-state.

Being confined to technical and economic areas, functional integration does not postulate the creation of a new sovereign power at a higher level. Instead, by trying to eschew politics, in terms of depoliticising communal issues rather than being inherently apolitical itself, it presents no immediate challenge to the sovereignty of states, which continue to survive as identifiable entities. ${ }^{33}$ As Taylor states: 'the functionalist approach, indeed, allows the view that there is no point at which the state would necessarily lose its sovereignty, in the sense that power would now need to be finally transferred, or that the state would lose its legal right to act, if it so wished, against the wishes of the functional agency. ${ }^{34}$ In particular, the 'functional imperative', as the basic law governing the evolution of the integration process, rejected the inevitability of constitutional requirements and fixed divisions of political authority, instead focusing on problems which, although they cannot really be ignored, cannot be solved separately by each government acting alone. This has been termed as the 'unitary trap. ${ }^{35}$

There seems to be a globalising, cumulative effect in the functionalist line of argument: once problems are recognised as common (or at least not essentially differentiated by the relevant community of actors), and solutions to these problems may arise from collective rational thinking, then there is a tendency to expand such co-operative behaviour to other relevant spheres of action. Does Mitrany's logic, however, necessarily avoid being trapped in the domain of 
conventional politics, where interests and preferences are shaped by traditional party political discourse and electoral considerations? The answer is that, despite certain elements of 'technical self-determination' embedded in the functionalist method, it does not always evade parameters of this kind. But there is another crucial point to be made about the political aspects of the functionalist logic, namely that functionalism is about the application of carefully examined, but not necessarily politically structured, strategies for transcending (national) territorial boundaries in tackling issues of a technical nature. Institution-building, in this regard, becomes conditional upon the (functionally determined) needs of the integrative system itself, rather than the preferred lines of action to be taken by national governments according to territorial interests.

However, it is not always easy to distinguish between 'non-territorial' and 'territorial' politics in the context of the Union's governance system, especially when a variety of actors pursues different, albeit not necessarily antithetical, interests and are motivated by different cultural traditions. In principle, however, not 'apolitical', but 'aterritorial', is a more appropriate term to describe the internal logic of functional arrangements. Functionalism in the Mitranian tradition is above all a theory of international society based on the principle of technical self-determination, reliance upon non-coercive means of international community-building, and an inherent mistrust of constitutional prescriptions of power-sharing. Mitrany's main concern was how to replace territorially defined structures of decision-making with international functional agencies, leading towards a 'working international system'.

\section{Federalism}

Federalism as an integration theory is much more relevant to the study of European integration than is often admitted. This is mainly owing to its increased concern about the dialectics of power-sharing in a compound political setting; its emphasis on in-built democratic arrangements linking different levels of governmental authority; its often flexible interpretation of the sovereignty principle; its focus on constitutional issues touching upon sensitive areas of individual and collective liberties, legislative representation and the allocation of competences; and its deeper concern about how to organise in a mutually reinforcing way the concurrent demands for 'unity in diversity'. Federalism, however, does not emanate from a single corpus of theory - a grand design, that is, which can be transplanted from one federal system to another without losing its internal (or systemic) relevance and cohesion. Rather, there can be different sets of principles and structures composing a federal polity. These, however, need to be seen in a wider symbiotic perspective: a creative co-existence of distinct but 'constitutive' units. Once one recognises these analytical constraints, it is possible to turn to the application of the various federalist designs to European integration and appreciate the diversity of their logic.

In general terms, federalism aims to reconcile the parallel demands for greater political union (but not necessarily unity) of the whole and adequate 
constitutional guarantees for the parts; namely, 'unity without uniformity and diversity without anarchy.' ${ }^{36}$ Thus the appropriateness of federal arrangements 'would appear to lie in those instances where the existence and vigour of the forces that press both for wider unity and for autonomous regional diversity are relatively balanced'. ${ }^{37}$ The striking of such a delicate balance emerges as the strongest catalyst for achieving overall 'federal cohesion' - itself a precondition for federations to survive the test of time. In Forsyth's words: '[Federal structures] establish a union but they simultaneously guarantee autonomy, and they fix or settle ratio or balance between the two. ${ }^{38}$ Or, alternatively: '[Federalism] is based on the existence of regional differences and recognises the claims of the component areas to perpetuate their individual characters. ${ }^{39}$ Here, democratic representation becomes a crucial factor for the political viability of federal units, highlighting the importance of accommodating territorial and non-territorial claims in nascent federal structures based on systems of common management such as the polity that is currently emerging in Europe.

Moreover, the representation of the people, either as a whole (when taken as a single entity) or as parts (when taken as a plurality of entities) becomes the prior object of the federation. ${ }^{40}$ 'What is distinctive about federations', King notes, "is not that "the people" are viewed as sovereign, but that the expression of this sovereignty is tied to the existence and entrenchment of regional, territorial entities.' ${ }^{41}$ In fact, 'one of the characteristics of federalism that flows from its popular base is the reduction of the question of political sovereignty to an incidental one', with the federal principle representing 'an alternative to (and a radical attack upon) the modern idea of sovereignty. ${ }^{42}$ Consequently, there are two possible, but not antithetical, ways of perceiving 'the people': as united and as diverse, a duality which 'for the life of the federation, is implicitly inexpungible. ${ }^{43}$ In both equations, however, it is the federal demos as a whole, rather than primarily the dominant political elites representing the interests of each constituent unit, which is to be served by the central arrangements.

Although federations encompass a considerable range of purposes, identities, cultural traditions, organisational characteristics and power-sharing arrangements, as well as different means of protecting the constitution, ${ }^{44}$ democratic representation of all participating communities emerges as a common defining property. The issue here is not so much about creating direct links between different levels of government but rather about establishing concrete and accessible avenues of communication between the demos and the central institutions. In speaking of such 'levels', one might assume that they are sharply separated from each other, 'like boxes piled on top of one another'. ${ }^{45}$ In reality, however, these different levels are never thus sharply divided. But if one considers that in most federal systems the central authorities are free to exercise considerable power over the federal demos, it is easy to explain why these direct links are central to the democratic legitimacy of the federal polity.

Unlike a unitary state model, the degree of democratic participation in a federal system is linked to the extent to which legislative autonomy in the form 
of 'reserved powers' (powers not delegated to the federal level) has been conferred on each participating collectivity by the Constitution. Thus public participation in the affairs of the federation is intrinsically woven into the degree of autonomous action granted to each level of government in which the demos exercises its sovereign rights. Further, the extent to which democratic diversity, or 'a co-ordinated expression of it, ${ }^{3}$ can be maintained without endangering the political cohesion of the federation is conditioned by the ability of the central arrangements to produce viable constitutional equilibria. Indeed, the intersection between federalism and democracy passes through the capacity of the compound polity to generate a common commitment to federal unity, while preserving the integrity of the constituent units. This implies that the idea of federation emerges as a living, pluralist and organic political order which 'builds itself from the ground upwards. ${ }^{47}$ Hence federalism as a multilevel political arrangement is based on a constitutional system of delegated, reserved and/or shared powers between relatively autonomous, yet interrelated, structures of government whose multiple interactions aim to serve the sovereign will of the federal demos. ${ }^{48}$

With the postwar circumstances in Western Europe corresponding, in Bowie's words, 'to those which often in the past have led nations to undertake the initial steps towards federation', the federal solution emerged as an inspiring remedy for Europe's multiple organisational problems. ${ }^{49}$ At the same time, the interposition of a central authority beyond pre-existing boundaries acquired, mainly thanks to Italian federalist thinking, the status of a desirable political ideology. Although the ideal of a united Europe predated the specific postwar attempts, what makes them unique is that 'the unity concept moved into the foreground of popular thinking with both an emotional and practical appeal. ${ }^{50}$ In a continent that was deeply shocked with the suicidal effects of nationalism, the federal impulse to postwar European unity rose as an attractive alternative to a challenge that, in Bowie's words, 'went to the very foundations of social existence.51

Far from conceiving the nation-state as an a priori fact of existence, the federalists regarded it as a 'historic accident' and proposed its transcendence by a process of 'rational federal development..$^{52}$ As a Draft Declaration by the European Resistance Movement in July 1944 put it: 'Federal Union alone can ensure the principles of liberty and democracy in the continent of Europe. ${ }^{53}$ Following this somewhat teleological line of thinking, any federal surrender of sovereignty seemed better than allowing the European state system to consolidate itself once more, especially after its 'great moral and material bankruptcy. ${ }^{54}$ Reflecting upon the 1944 Ventotene Manifesto, Bosco has observed: 'The real cause of international anarchy was seen as "the absolute sovereignty of national States", which is the source of power-politics in the international sphere and of totalitarianism in the national one. ${ }^{55}$ Similarly, Spinelli has argued that the nationstate had become 'a compass which had ceased to give any bearings'.56 These statements provided the moral justification of early federalist designs. The 
choice of European nations was one between federalism and anarchy, rather than between the former and some measure of interstate co-operation.

The federalists also argued their case by stressing the inability of states to provide new means of popular participation, and that an unprecedented 'legitimacy crisis' had shaken their once powerful structures: a deep-rooted structural crisis which prompted them to look above the nation-state itself as a means of resolving its acute legitimation problems. Underlying these criticisms is a belief that 'new loyalties will arise in direct conflict with the nation-state, ${ }^{57}$ opening up much wider horizons than those afforded by the latter. This is exactly what European federalists had in mind: that these multiple pressures on the nation-state would lead to the recognition that new democratic arrangements would have to be devised so as to meet the challenges of the post-1945 era. Spinelli, for instance, had strongly opposed the idea proposed by national governments of a 'partial' European union without first creating a democratic infrastructure upon which common institutions would be based. In this sense, federalism provided the means not only to overcome the structural crisis of the nation-state itself, or even 'to transform the very essence of national statehood into a larger loyalty going beyond its territorial affinities', ${ }^{58}$ but also a powerful stimulus to the extension of the democratic process.

Whatever the title ascribed to the envisaged polity, it was widely recognised that it would have to strike a balance between interdependence and autonomy, democracy and efficiency and, above all, unity and diversity. To convince the European peoples of the merits of federalism as a means of safeguarding their cultural and political traditions, the federalists stressed the representative character of the central institutions. It was maintained that the latter should be left free to exercise the political authority conferred on them by a written constitution in direct relation to the European public without having to rely upon the convergence of short-term national interests for the formulation of common policies. Herein lies federalism's greatest contribution to the cause of European unity: in the 'inclusive' political community, power and responsibility should be seen as being mutually supportive, rather than as a competitive tussle for political authority between the collectivity and the segments.

Writing on the strategic aims of the Federalist Movement, Levi refers to 'the objective of changing the character of exclusive communities which nationstates have and unifying them in a federal community thus transforming them into member states of the European Federation, in such a way that they can coexist peacefully though maintaining their autonomy. ${ }^{59}$ It was believed that federalism would encourage democratic diversity by establishing a system of coordinate but independent spheres of authority based on a division of power among state and federal agents. According to this scheme, the component legislatures would hold their executives accountable to their respective publics, while a European legislature would act as a potential barrier against the danger of central executive dominance. Resting upon a 'firm constitutional structure', the main powers of the federation were to lie in the sphere of defence, foreign affairs, 
commerce across state lines, international exchange, communication and, in Pinder's words, 'enough tax to sustain the necessary expenditure. ${ }^{60}$ On the whole, the envisaged pattern of federal-state relations was closer to the dualistic model of classical federalism, requiring a constitutional separation of powers between state and central authorities, rather than to a system of 'shared rule' based on concurrent competences, which were seen at the time as a potential source of internal disputes.

It soon became evident, however, that if the federal project was to be crowned with success it would have to overcome national governmental resistance to an immediate relinquishing of state sovereignty to a federal polity. The solution to this problem came from Spinelli, proposing a strategy based on a campaign of public persuasion for the drafting of a federal constitution. This task was to be carried out by a directly elected European Constituent Assembly. ${ }^{61}$ The justification of Spinelli's 'constituent method' lay in the belief that such an assembly was the only acceptable body to transform the possibility of popular participation in the affairs of the federation into political reality. The constitution was to be based on a declaration of fundamental rights, democratic institutions and the separation of powers: it was believed that a balanced structure of national and federal competences based on the principle of dual federalism would preserve national identity and diversity in a way compatible with the democratic ethos. Thus it was agreed that the federation should have limited but real powers, with the remaining spheres of competence resting on state jurisdiction. In short, the gist of the federalist thesis was that 'federalism is the only international democratic bond which can create a reign of law among nations', as well as the only possible means for enlarging 'the sphere of democratic government from the ambit of the state to that of a group of states. ${ }^{6}{ }^{2}$ As most federalists have acknowledged, however, the difficulty of the task lay not so much in convincing the European peoples of the need for a federation, but in convincing them that they, rather than their national governments, must create it. This brings us to the very limitations of European constitution-making, to which we now turn.

The first real test for the idea of creating a federal Europe came with the 1948 Hague Congress. Yet its end product, in the form of the Council of Europe, did not live up to federalist expectations. Rather, it represented 'a triumph of the unionists. ${ }^{63}$ As the Federal Movement was losing whatever popular appeal it initially displayed, an alternative method of institutional development started to consolidate its strength: Monnet's 'functional federalism'. Being functionalist in conception but federalist in prospect, this approach represented a new, albeit modest, integration philosophy. Convinced that European unification was not interested in 'end situations' as in evolutionary processes, the functionalists criticised the federal alternative for being totally impractical and idealistic, 'offering', in Harrison's words, 'merely the prospect of the unattainable. ${ }^{64}$ Instead, by recognising that integration had nothing to do with formal constitutional engineering, the functionalists stressed the point that Europe could not 
be unified 'by a stroke of the constitutional lawyer's pen'. ${ }^{65}$ They criticised the federalists as advocates of an immediate objective which was largely overtaken by a naive sentimentalism, deceiving themselves with the illusion of radical political change. Likewise, Spinelli's pathway to unification was viewed as overambitious and legalistic, resting on the fallacious assumption that the termination of the war had also signalled the 'withering away of the nation state'. In general, the federal projects were believed to be consciously undermining the necessary gradualness of integration in order to achieve a rigid constitutional settlement, thus losing sight of the dynamics of 'functional incrementalism' as its major characteristic.

The early school of European federalism, by relying heavily on the American federal experience, seemed to have undermined the sui generis character of postwar European integration. In their unrestrained passion for a united Europe, Beloff asserts, federalists were misguided in looking to the US pattern for a promising analogy. ${ }^{66}$ In Albertini's words, 'as a new form of the modern state, federalism is an American product. But the United States of America had not to overcome historically constituted nations to constitute itself. ${ }^{37}$ In contrast, the federal conception of Europe failed to recognise that such a vision was not the primary goal for a sufficient number of Europeans. Likewise, its constitutive principles did not acquire sufficient persuasive power to win the confidence of national governments. But it would be unjust not to reiterate the commitment of European federalists towards a democratic process of union, and their opposition to an essentially utilitarian form of interest convergence as a precondition for any substantive public loyalty transfers. For they unequivocally maintained that parliamentary democracy was too closely related to Europe's political culture to be denied beyond the state level. Finally, it was they who first stressed the importance of linking the idea of a European Constitution with the legitimation of the larger polity based on a parliamentary (bicameral) system of government.

\section{Confederalism}

Just as a federal state differs essentially from a unitary one, so does a confederation from a federation. Whereas the latter is based on a constitutive act which creates a higher, superordinate legal order, a confederation is based on a foedus or treaty among sovereign states. It thus represents a 'contractual union of states' in which the participants voluntarily decide to band together by way of 'mutual agreement' in order to transform their existing patterns of relations into something akin, yet not identical, to the internal relations of one state. ${ }^{68}$

Sharma and Choudhry have described the distinction between these models thus: 'a confederation is a loose union over confederating independent states, whereas a federation is a union deriving its authority from the citizens of the union'; 'a confederation is the outcome of an agreement or treaty made generally for a specific period ... whereas a federation is the result of a true constitution supreme over all other instruments from which both [levels of] 
government $[s]$... derive their respective powers'; 'in a confederation, the powers of the common body or authority are narrow and extremely limited, whereas in a federation the powers of the general government are wider, largely exclusive, and capable of being exercised through its own agencies'; 'in a confederation, the units are free to dissociate themselves from the union, whereas in a federation the units are united with the general government on a co-operative basis'; 'in a confederation the units retain their sovereignty, whereas in a federation the authority of government is shared by them with the general government'; and 'in a confederation the general government is subordinate to the regional governments, whereas in a federation the general government co-exists with the regional governments and is independent from them. ${ }^{69}$

From a different perspective, in the case of the confederation, a plurality of previously independent states gives way to a 'treaty-constituted political body'70 in which "the condition of "the last say""71 rests with the partners to it, rather than with an independent authoritative entity having a monopoly of legislative and coercive powers. Hence Forsyth views confederation as being 'far more directly a contractual creature than the normal state', manifesting itself not as 'the constituted unity of one people or nation, but a unity constituted by states. ${ }^{72}$ He explains: 'the constitution of a confederation is not, by definition, the unilateral act of one people . . . considered as a homogeneous entity . . . a confederation is formed precisely because a nation or people in this sense is not deemed to exist, because the sense of identity and thus of trust between the citizens of each member state does not run to that depth. ${ }^{73}$

In practice, a confederation takes the form of a 'half-way house' between 'normal interstate' and 'normal intrastate relations', with the constituent units reserving the right of self-determination: 'it is a union that falls short of a complete fusion or incorporation in which one or all the members lose their identity as states. ${ }^{74}$ Or, as defined by Elazar: 'Several pre-existing polities joined together to form a common government for strictly limited purposes ... that remains dependent upon its constituent polities in critical ways and must work through them.'75 This type of union, similarly to a 'mutual pact' among selfdetermining bodies politic, signifies a 'joint agreement to be independent." ${ }^{76}$ Forsyth explains: 'The contract which lies at its base is not a contract to abide by the will of the majority regarding the government to which all shall be subordinate, but simply a contract between equals to act henceforth as one. ${ }^{77}$ This is not to imply that a confederation possesses merely a 'legal' personality of the type of 'conventional' international organisations. Rather, it is capable of developing a 'real' personality of its own: 'an original capacity to act akin to that possessed by the states themselves. ${ }^{78}$ The underlying characteristic of a confederation as 'a system of governments' is that it provides the component parts with a variety of opportunities to achieve mutually advantageous co-operation without resigning their individual sovereignty, by focusing on intergovernmental relationships between a number of legally and politically equal centres of authority, rather than between them and a single federal government. 
According to the German political theorist, von Treitschke: 'A Confederation of States ... is recognised by international law as an association of sovereign States, who have bound themselves together, without resigning their independence, to further certain common goals ... Consequently the members of a Confederation exercise their natural liberum veto. ${ }^{79}$ In other words, although confederations may have a considerable freedom in determining their internal organisational structures, 'they cannot as organisations make general rules or measures which are directly binding upon the states that create them. ${ }^{80}$ Forsyth makes the point well: 'Thus the individual states must give their express assent, or at the very least withhold their express dissent during a fixed period, before a convention, treaty, or any kind of general resolution made within or by an interstate organisation becomes binding upon them. ${ }^{81}$ All in all, confederations do not fundamentally challenge, at least in constitutional terms, the legal capacity of the constituent units to determine the fate of their own polities. In this context, the idea of a 'condominium of powers' in which the management of certain policy areas is voluntarily put into a limited but joint pool of sovereignty does not conflict with the above description. ${ }^{82}$

Moreover, Forsyth argues that 'the permanence accorded to a confederation is more than merely the standing "disposability" of the institutions of the typical international organisation. ${ }^{83}$ Instead, 'it is a profound locking together of states themselves as regards the joint exercise of fundamental powers', driven by a common determination to prevent hegemony and, hence, a monopoly of power..$^{84}$ Accordingly, confederation can also be seen as a process by which a group of separate states commit themselves by a treaty of union to mutually beneficial interaction which may well extend beyond the traditional patterns of international co-operation. And since it aims to reconcile the concurrent demands for preserving the sovereignty of the parts, and with it the integrity of their populations, and for maintaining high levels of co-ordination among them, this model is indeed capable of embracing a wide range of institutional possibilities. Thus it can be conceived, in line with Friedrich's dynamic model, as a 'federation-to-be', ${ }^{85}$ or even taken to denote, according to Forsyth's theory, a 'genuine federal body', albeit of a looser kind, insofar as the constituent units become parts of a new whole. ${ }^{86}$ In short, irrespective of whether the analytical dichotomy between the two forms of polity springs, as Friedrich believes, from 'the quintessence of the static and formalistic approach, ${ }^{87}$ what seems to be certain is that the concept of confederation 'remains a useful part of the federal vocabulary' ${ }^{88}$

The literature on confederation has impressed upon a number of scholars over the years in their attempt to classify the defining properties of the Union. The confederal character of the system has been pointed out by a number of scholars, summarised by Keohane and Hoffmann thus: 'If any traditional model were to be applied, it would be that of a confederation ... since the central institutions are (a) largely intergovernmental, (b) more concerned with establishing a common framework than with networks of detailed regulations, and (c) apparently willing to tolerate a vast amount of national diversity. ${ }^{89}$ Similar 
descriptions of the Community are to be found, inter alia, in the subtitle of an article written by Brewin - 'A Union of States without Unity of Government'; in Church's prototypal term 'confederence' as a means of capturing its intrinsic confederal properties; and in Elazar's characterisation of the Community as a 'new-style confederation of old states. ${ }^{90}$

The justification of the confederal approach to the study of European integration is that the evolution of the Community system has been shaped by arduous intergovernmental bargains among sovereign states, as well as by an attempt to accommodate their varying preferences in a mutually acceptable way, that is, without threatening what they have often perceived as their vital national interests. In this context, the idea that the larger entity is based on an international treaty, rather than a European Constitution, is also supportive of its essentially confederal character. What this view often fails to take into account, however, is the legal dynamics of integration and the political activism of the European Court of Justice (ECJ) in the process of 'constitutionalising' the treaties. Yet it is doubtful whether subsequent amendments to the founding treaties have brought about a higher constitutional order, at least when measured against the constitutional properties of the member nation-states. Rather, it seems that the larger political unit rests upon the separate constitutional orders of its component parts which, by virtue of their sovereign nature, continue to act as 'Masters of the Treaties' (Herren der Verträge). The mere fact that formal treaty change requires the unanimous consent of the member state governments underlines this point.

At the decision-making level, there is a case to be made against the confederal approach in so far as majority rule applies in the Council of Ministers. Yet, clear as it may be that states may well be outvoted in a number of policy areas, there is a tendency to treat the dissenting states with extreme caution when national interests are at stake. Hence the contention that more often than not it is the threat of invoking the right to veto, in accordance with the provisions of the Luxembourg Accords, that has a crucial impact in the negotiating process, resulting in most cases in 'package deals' of an accommodative nature. Another point which prima facie seems to contradict the confederal approach is that the European Parliament (EP) is the only directly elected international Parliament, possessing limited but effective co-legislative powers. Again, true as it may be that the EP acts as a source of the Union's democratic legitimacy, it remains far from being regarded as a Parliament in the conventional sense, since it still lacks the power to initiate legislation, to have a prominent role in setting the Union's legislative agenda, to hold collectively into account the Union's main legislative body (the Council) for its actions or inaction, to elect a single European Government, to hold its elections under a uniform electoral procedure, and so on. More importantly, there is evidence to suggest that the Union is characterised by a fragmented citizen body rather than a politically self-conscious European demos, capable of directing its democratic claims to, and via, the central institutions. This is a point that needs to be made in relation to the democratic 
properties of federal polities where a composite demos exists and forms the 'constitutive power' of the federation.

\section{Transactionalism}

The approach developed by Deutsch in his examination of the North Atlantic Area represented a shift in emphasis from the early theoretical endeavours of functionalists and federalists to a more empirically oriented framework of analysis. This was a systematic attempt to capture the relationship between international integration (largely seen as a process of community-formation) and social communication (changes in patterns of transactions), by focusing on the conditions which may bring about a large-scale 'sociopsychological community'. Deutsch defined integration as 'the attainment of a "sense of community" and of institutions and practices strong enough and widespread enough to assure, for a "long time", dependable expectations of "peaceful change" among its population.' ${ }^{91}$ That could be achieved through processes of mutual transactions, cultural flows and social learning. Prominent in his argument was the idea of peaceful problem-solving through the intensification of avenues of communication among nations. This he called a 'security community': a framework of social interactions where war would eventually become in the relevant region both unthinkable and impractical. Deutsch's notion of 'security community' could be either 'pluralistic' or 'amalgamated', although he never really implied that there was an automatic forward linkage between these two different types of organisation.

Deutsch was not particularly concerned with the institutional configuration that the integration process would bring about. Nor was he especially interested in the allocation of authoritative power among different levels of decision-making. His research focused on the sociopsychological aspects of community-formation, which was seen as a result of increased and 'mutually responsive' transactions among its constituent parts. But it would be unfair to the logic of his approach to present the developments in transactions solely as an indicator of community-building. Taylor explains: 'It is also important to point out that it is the range and quality of changes in transactions that constitutes an indicator of community: too frequently Deutsch's ideas are criticised on the mistaken assumption that he sees particular transactions as equivalent to developing community. ${ }^{92}$ The end product of integration would take the form of an identifiable community of citizens - that is, a people - through a process of social learning. Although such an outcome would take a long time to materialise, in fact several generations as Deutsch suggested, what is important is that the 'uniting parts' would start to develop 'a sense of community' based on the power of common identities, shared values and belief systems, and a common perception of their destiny, and that certain norms and habits of societal interaction would emerge from the range and intensity of informal contacts. Community feelings, therefore, were seen as the result, rather than the cause, of closer links among the participating units. 
The distinction made by Deutsch between a 'pluralistic' and 'amalgamated' security community warrants closer attention. The former was expected to produce a 'sense of security' among the relevant populations, whereby the resolution of conflicts through violent means would be replaced by mutually acceptable methods for their peaceful settlement. It was the particular attitudes of the actors involved that would create a certain culture of co-operation which, through the forging of further and closer communicative links among them, would make resort to war highly unlikely. On the other hand, Deutsch's idea of an 'amalgamated' security community was a more advanced form of political community, closer to the type of Gemeinschaft (or community) depicted by Tönnies in the late nineteenth century. ${ }^{93}$

In this type of association, as opposed to the more 'instrumental' notion of Gesellschaft (or society), one may perceive the embryo of a genuinely 'constitutive' community: 'a community that would constitute the very identity of the individuals. ${ }^{94}$ Gemeinschaft is more suitable for the prospering of mutually responsive relations since the individuals forming it have developed to a sufficient degree a 'sense of community', also known as 'community spirit' or 'community of attachment', strong enough to overcome, and even transcend, any potentially divisive issues which may arise as integration proceeds. Equally, where the 'community spirit' is less profound, integration will find it more difficult to cope with internal disputes. In this sense, the 'Gemeinschaft factor' appears as one of integration's indispensable 'common spheres'.

Although no actual society or institution will ever conform completely to Tönnies' theoretical selections, ${ }^{95}$ since they are conceptual entities representing two ideal types of social organisation, Deutsch was aware of the fact that a sociopsychological community would have to be based on 'a sense among the individuals forming it of belonging together, of having common loyalties and values, of kinship', so that the tasks performed within its structures would stem from 'a feeling of contributing something worthwhile to the good of the whole. ${ }^{96}$ Thus a Gemeinschaft is something qualitatively distinct and higher than the numerical sum of the private well-being of its members. In this type of community, people associate themselves together because they think of their relationship as valuable in the dual sense of being important both as ends in and of themselves. It is perceived as an internal, living and organic 'collective entity' - organic in terms of being considered and conceived of in relation to its parts ${ }^{97}$ - whose 'norms of order' are based upon 'concord', as opposed to a Gesellschaft which rests on a contractual arrangement or 'convention'.

Resting upon relationships of mutual affirmation of a federative kind, the members of a Gemeinschaft gradually develop strong feelings of 'togetherness', 'we-ness' or even 'oneness', to the eventual framing of a collective consciousness. Accordingly, these individuals are bound together in symbiotic - that is, mutually reinforcing - relationships, thinking of their collective existence as dominating their respective individualism, while perceiving their close association as a means of improving their domestic conditions of living. In short, an entity 
which is formed through this positive type of relationship points to 'a lasting and genuine form of living together', as opposed to its counterpart form of 'human Gesellschaft', which is considered as a mere co-existence of people independently of each other. ${ }^{98}$ Therefore, whereas the 'common sphere' of a Gesellschaft rests on the concept of contract, with its 'secret' lying in 'a rational coming together of ends that remain individual', ${ }^{99}$ that of a Gemeinschaft rests on the concept of 'one people', with its 'secret' lying in an 'internally oriented relationship' developed among its members, rather than in a mechanical or artificial fusion of separate, private wills. Also, in Gemeinschaft-like relationships the ensemble of individual wills mutually direct each other towards an 'equilibrium of forces', with authority not being viewed as an all-powerful decision-making centre, but rather as a dialectical process of structuring civic relations. ${ }^{100}$

According to Taylor, Deutsch's sociological approach 'concentrated more on description and was more cautious about predicting the dynamic links between the various stages of the integration process. ${ }^{101}$ This distinguishes him from the analysis of neofunctionalism and the premium it placed on forward linkages. Being interested in the early stages of community-formation and the relationship between different conditions of the integrative process, Deutsch's analysis is also easy to distinguish from the early federalist school of thought and its emphasis on the constitutional prerequisites of European unification. In fact, Taylor notes, 'Deutsch's pluralistic security community contains no common decisionmaking centres ... but in some ways it is highly integrated'. ${ }^{102}$ Institutionbuilding, therefore, is not treated in mainstream Deutschian analysis as an end in itself or as a primary indication that integration has indeed taken place. Rather, the emphasis lies at a different level of analysis: the development of a sense of community at the popular level. In this, Deutsch shares a common belief with the older functionalists: the higher the level of sociopsychological community and, hence, of consensus in society, the greater the progress towards the integration of the segments into a larger purposive whole - i.e., 'a community of attitudes and values' - and the less controversial the process of transferring substantive powers to a new regional centre.

\section{Neofunctionalism}

Next comes neofunctionalism, which is often but mistakenly associated with Monnet's 'functional federalism'. The latter term has been employed as an analytical tool to explain the composite character of Monnet's gradualist approach to integration, amounting to a rather eclectic synthesis of elements of functionalism and neofunctionalism, without however being fully in accord with either. Neofunctionalism, therefore, should not be hastily classified as being - conceptually or otherwise - in limbo between functionalism and federalism. Although it shares some important elements of both schools (from functionalism the centrality of transnational actors and from federalism that of the central institutions) it has developed its own integrative logic, subscribing to certain principles and values of transnational interaction, dynamics of institution-building and 
styles of collective decision-making. In fact, the contribution of neofunctionalism, an American-bred school of thought led initially by Haas, ${ }^{103}$ has been unique in the study of European integration.

Most notably, neofunctionalist thinking inserted the element of conflict in the analysis of the regional process, as well as that of forward linkages among different, yet interrelated, policy arenas. Procedural mechanisms were seen as decisive, whereas the idea of a sociopsychological consensus at the popular level, a variable indirectly linked to Mitrany's philosophy of international integration, was not taken as a prerequisite for the transfer of authoritative decision-making power to a new regional centre. Rather, such a consensus, which in a way corresponds to the idea of a less polarised form of society, emerges as a latent property and/or a consequence of successful elite socialisation: the process by which influential factors of policy and decision-making from different national settings learn to work with each other under the institutional umbrella of a larger management system. In this context, a process of bureaucratic interpenetration or engrenage, emerged as the dominant modus operandi of the regional system. The idea is that different actors decide to shift their focus on collaborative action to the point that competences - functional and jurisdictional - become blurred, identities overlap and loyalties co-exist. Mutual reinforcement is a key to understanding the logic of neofunctionalist 'spillovers' in functionally and/or politically relevant policy arenas. Progressively, there will be a convergence of demands on the parts of governments and a propensity for further integrative action, facilitated by the new central authorities. The spillover effect may take three different forms: functional (technical pressures leading towards further integration), political (as a result of intensive levels of elite socialisation) and cultivated (through the role of the central bureaucracy).

An essential part of the neofunctionalist strategy was the identification of the Community Method as the new modus operandi of the integrative system. Such a 'method' consisted, inter alia, of high levels of elite socialisation, joint lobbying activities of organised interests, the Commission's right of legislative initiative, the involvement of national governments in complex negotiations at the European level, and a certain culture on the part of the Commission for upgrading the Community interest. It was not accidental, therefore, that in the early stages of the Community's development, neofunctionalism acquired the status of an ideology in Brussels. As Milward and Sørensen put it: 'the theory's technocratic elitism appealed strongly to European Community officials who naturally saw the extensive theorizing about the workings of the Community as a confirmation of their historical role as guardians of European integration processes. ${ }^{304}$ This line of argument chimes well with Monnet's philosophy of integration. According to Mutimer, 'neofunctionalism ... provides relative rigorous formulation of the means of political integration developed ad hoc by Jean Monnet and his colleagues in the 1950s. ${ }^{105}$ Likewise, Monnet's pragmatic method was in line with Haas' dictum that 'functional integration requires pluralism'. 
Taken as a dynamic process rather than a condition, the end product of integration remained an open-ended one. Even Haas' definition of 'political community', ${ }^{106}$ as a possible end situation where loyalties are transferred towards a new centre, leaves much to be desired from an organisational point of view. The reason for this 'reluctance' to identify a terminal state of integration can be traced in the logic of neofunctionalism itself: having stressed the idea for an inner compulsion towards integration, 'in that the creation of common institutions would set in motion a process for the accumulation of wider functions', it would be too risky an endeavour to reach any authoritative conclusion on the political properties of the envisaged European polity. Neofunctionalists would often go as far as to state that the very incompleteness of the project would create the need for new central arrangements and, in time, for a directly elected EP to ensure democratic control over the larger, and by then federated, European 'community'. From the outset, however, direct democratic legitimacy was not viewed as a prerequisite for entrusting the new institutions with the political management of the larger entity. Attributes like 'political community', 'supranational authority' and 'federal union' add little to the precise institutional form the end product is expected to take. Perhaps the only relatively discernible outcome of integration in neofunctionalist terms is the creation of what Harrison called a 'self-regulating pluralist society' ${ }^{107}$

Moreover, the neofunctionalists, by abandoning the central integrative role of attitudinal change while exhibiting a strong normative commitment to elitedriven integration, placed the emphasis on a 'procedural consensus' about the institutional rules of the game: they stressed 'the psychology of elites in an integration process ideally culminating in the emergence of a new political system. ${ }^{108}$ Further, they conceptualised integration as resulting from what Haas called an 'institutionalised pattern' of interest politics. ${ }^{109}$ Such concentration on institutional developments had important implications for their conception of sovereignty. Taylor writes: '[neofunctionalists] implicitly accepted the view that sovereignty is strengthened by an expanding legal competence. ${ }^{110}$ Further, it was crucial for the common system to operate under conditions of economic and political pluralism, driven by what has been described as 'the expansive logic of integration'. The latter, once in train, was expected to transcend, and for the more optimistic even replace, existing nation-state structures. Implicitly, the neofunctionalists envisaged the development of a new regional government composed of a highly interactive community of actors.

But the important element remained firmly confined in the process of integration itself: successive spillovers would bring together previously unconnected policy arenas and demand a change in both the behavioural and operational attitudes of the 'relevant elites'. In this respect also, the Commission, in its function as a collegiate body, was to occupy the major role for Europeanwide policy change. It was assigned the task of acting as the motor of integration, the source of integrative initiatives and the centre of technical expertise for launching joint projects of a supranational character. The point to make here is 
that the Commission, in contradistinction to its predecessor (High Authority), was given a wide range of policy competences to influence, along with the Council, the common legislative process, and to be significantly involved in the process of setting the integrative agenda. This was especially true until the establishment of the European Council in the mid-1970s and the changing role and dynamism of the Presidency arrangements thereafter.

Although neofunctionalism stressed the importance of 'conflict' in the integrative process, it failed, initially at least, to distinguish between the 'scope' and 'level' of integration. The former refers to the range of the central arrangements in the form of policy arenas that become part of the region's integrative corpus - specific functions, that is, that are commonly managed at the larger level. On the other hand, the 'level' of integration refers to the ways in which such functional areas are managed, the involvement of supranational institutions in the shaping of common policies, and hence the extent to which the central institutions are capable of exercising political authority independently of national political institutions. Neofunctionalist thinking, certainly before Schmitter introduced the notion of 'spillaround', assumed that the scope and level of integration are mutual reinforcements: the more you bring into the common framework of interests and power new policy areas, the greater the involvement and, subsequently, the influence, of supranational institutions.

Consequent amendments to the original treaties, however, point in the opposite direction. For example, in the case of the SEA, although there existed a feeling of accomplishment among European leaders for overcoming some of the obstacles towards further market integration (in the sphere of negative integration), greater majority rule-making in the Council and more attention to issues of economic and social cohesion, the level of integration was not fundamentally altered to take the system closer to a federal polity. However, the scope of integration was significantly advanced to include new areas of transnational cooperation. A similar view may be adopted for the TEU, the AMT and the NIT which, taken together, do not alter the locus of sovereignty from national to supranational institutions of governance. These revisions add to the political dynamics of integration, but not to the formation of a European polity whose constitutional properties would present a direct threat to sovereign statehood.

Neofunctionalist theory has also been criticised on the following grounds: projecting a supranationally biased image of Community arrangements and dynamics; overestimating the role of the Commission as a policy initiator; overstressing the role and influence of organised interests at the larger level; offering an 'elite-driven' explanation of the Community's internal workings; not taking into account 'the logic of diversity' in the regional system; being overtaken by events, especially after the first major constitutional crisis of the Community in the mid-1960s; underestimating the viability of national polities; failing to distinguish between 'low politics' (spheres of technical co-operation) and 'high politics' (foreign policy and defence); ignoring the high levels of interdependence in the global arena, and so on. In the end, it was Haas himself who, in the 
mid-1970s, critically refined some of his earlier formulations, most notably the automaticity of the spillover effect. ${ }^{111}$ As Church has rightly summarised the debate: '[neofunctionalist] predictions proved empirically wrong . . . the states of western Europe did not lie down and let supranationality walk over them. ${ }^{112}$ Yet he is equally right to point out that neofunctionalist theory 'was the first really deep and complex explanation of the Communities.' ${ }^{113}$

\section{Theorising in the 1970s}

\section{International regimes}

As neofunctionalism was gradually denounced in the late 1970s, a sense of renewed theoretical excitement was set in train by other, equally sophisticated, approaches, regime theory and interdependence theory being among the most prominent. The former brought into the debate the question of whether institutions really mattered in processes of internationalised governance - in the case of the Community, capable of producing publicly binding decisions - whereas the latter portrayed a dynamic system of increased interconnectedness, functional and structural, which set the pace and, to a certain extent, the depth of the regional management arrangements.

International regimes justify the separateness of states as constitutionally distinct entities. As Taylor put it: 'states do not cease to be states because they are members of a regime.' ${ }^{114}$ At the same time, regimes allow states to 'socialise' with each other in a complex web of norms of behaviour, rules and procedures of decision-making that are commonly, if not ex ante, agreed upon by the participating actors. The emphasis is on informal routes of co-operative behaviour, patterned as much by specific political interests - although it has been argued that regimes imply 'a form of co-operation that is more than the following of short-run interests' ${ }^{115}$ - as by a common tendency to pursue (but not necessarily explicitly set as such) reciprocal objectives. Regimes project a certain understanding of regional international co-operation: an 'inclusive' framework of multiple and, more often than not, complex interactions which reflect a given political reality. In the case of the Community, it could be argued that regimecreation, as in the case of the European Monetary System (EMS) in 1979, was directed at setting the limits of acceptable behaviour within a structure of collective, yet flexibly arranged, governance.

Although the influence of American-led international relations literature became immediately manifest in the discussion of the Community as an international regime (or as a system with significant regime characteristics), the latter concept remained conveniently vague as to embrace a multiplicity of different manifestations concerning the management of complex interdependencies, to the extent that almost every aspect of transgovernmental co-operation, whether stemming from a treaty-based mandate or from 'extra-treaty' arrangements, was classified as one type of regime or other. Cox's definition of regimes 
illustrates this point, '[Regimes] are ... recognised patterns of practice that define the rules of the game,',16 as does Krasner, describing them as 'sets of implicit and explicit principles, norms, rules and decision-making procedures around which actors' expectations converge in a given area of international relations. ${ }^{117}$ A somewhat different account is offered by Young, who defines regimes as 'social institutions governing the actions of those involved in specifiable activities or set of activities. ${ }^{118}$ The emphasis here is on rules that are translated into 'well-defined guides to action' and on compliance mechanisms with the rules governing the regime. There is a certain procedural bias in this view, in terms of the actors' expected actions 'under appropriate circumstances.. ${ }^{19}$

Different interpretations of these elusive constructs come from authors who focus on the norms that regularise the behaviour of actors and guide their choices. Norms constitute 'standards of behaviour defined in terms of rights and obligations. ${ }^{120}$ The question here is: can norms transcend possible sources of tension among regime actors stemming from what Scharpf calls 'the self-interestedness of governments'? ${ }^{121}$ If 'yes', then through which accommodationist mechanisms do actors reconsider their choices and decide to comply with a certain pattern of behaviour which is acceptable to their partners? This is no ontological issue; it is about the flexibility of the regime in question, the way in which it is valued by the participants, and the means by which norms can facilitate the reaching of agreements on the basis of mutualism and reciprocity. In a word, what are the limits of consciousness-raising that a regime can generate? These questions have serious theoretical implications when examining the major crises in the history of the Community, from de Gaulle's 'empty chair policy' in the summer of 1965 , to the budgetary crisis of the early 1980s, to the negative Danish vote on the TEU in June 1992. ${ }^{122}$ A common thread in these episodes was that the dissenting state did not seriously contemplate the possibility of withdrawing from the common regional system - an indication that regime analysis remains an important part of EU theorising. ${ }^{123}$

What regime theory found difficult to transcend, however, was the role of national establishments in dealing with issues relating to the level of integration, rather than merely its functional scope. Although the concept was capable of explaining why international co-operation does not necessarily take place within an anarchical environment, or even why it creates conditions conducive to structured interactions, regime analysis fell short of explaining the intensity of relations resulting from the regional process and the extent to which the structural properties of the system - that is, the treaty-based nature of the Community and the reality of mutual vetoes in the Council - could determine the level of integrative arrangements at certain points in time. True, regimes may account for the institutionalisation of multilateral relations in specific fields, but they do not offer any structured analysis of the nature of power-politics and interest differentiation among the participating actors. The conceptual lenses used by regime theory are often part of a largely normative interpretation of internationalised co-operation: namely, that states will play by the rules of the 
game, as of course set by themselves. Purely political considerations may then be subordinate to a functionalist explanation of collective action, overemphasising the actors' initial commitments.

In particular, where the degree of commitment exhibited by the constituent parts varies according to the stakes involved in the process, or in fields of co-operation where governmental activity rests primarily within the domestic arena, regime theory faces a difficult challenge: it has to take account of the more formalistic networks of relations developed by the Community (legal) system, where the influence of non-territorial institutions such as the Commission and the ECJ is of significance. Thus, like interdependence theory, regime analysis is often trapped in a rather dispersed or loose framework of exchanges among policy actors, undermining the impact of the Community's legal order (or its legal authority, for that matter) on shaping national patterns of behaviour and limiting their preferred options - that is, compliance with detailed Community regulations.

Another area of concern is that the Community is too fragmented a system of policy interactions to be treated as a single international regime: it needs to be differentiated according to the specific conditions of co-operation in its various policy sectors. Under this line of argument, the Community system could be seen as a multilayered structure of partial regimes, encompassing a multiplicity of different norms of behaviour and rules of the game (especially when different legislative procedures apply which determine the degree of involvement and strategy of the relevant actors). As Wallace put it with reference to the EC budget, 'the difficulties which the Community so far faced in agreeing on the objectives which the budget should serve ... and the policies and priorities it should support, offer sobering evidence of the incompleteness and incoherence of the partially integrated policy-making system which it represents. ${ }^{124}$ Further, a partial conceptualisation of the Community's 'policy regimes' is not particularly helpful when assessing its cross-sectional, essentially political properties that is, what defines it as a political system.

The proliferation of extra-treaty arrangements in the late 1970s stemmed from a deeper concern on the part of the national executives to reassert a considerable degree of national autonomy in the handling of their internal affairs within a sensibly arranged framework of complex interactions. In this respect, regime theory failed to take into account the relationship between the politicisation of issues that regional integration produced and the strategy employed by particular state actors to exercise managerial control over the integration process. These deeper concerns have as much to do with implied benefits from collective action (or regime maintenance) as with questions of an ideological nature about what kind of integration is allowed, or indeed prohibited. In fact, viewing the Community through the relatively modest lenses of international regime theory risks missing important points about the dynamics of formal interinstitutional linkages at the regional level and the importance of domestic politics in shaping transnational affairs. Perhaps this is the strongest critique of 
regime analysis as applied to the European integration process: politicisation and grassroots democratic concerns often determine the limits of regime formation at the larger level - they provide a clearly defined set of conditions about the legitimation of systems of common management.

\section{Interdependence theory}

'Interdependence' was put forward by students of the Community as a more analytically profitable term than 'integration', partly as a result of the unfulfilled objectives of political union in the mid-to-late 1960s, and partly due to the dominant role that national governments continued to enjoy in the management of Community affairs throughout the 1970s. In fact, one of the consequences of the Luxembourg Accords was not only the preservation of a decision-making culture in the Council of Ministers in favour of consensual outcomes, but also the gradual marginalisation of the Commission's influence over the domestic political orders of states. After the deterioration of the international economic environment in the early and late 1970s, a common thread emerged among the member state executives for the maintenance of a considerable degree of autonomy over their internal affairs against any potentially ambitious integrationist design, either in the field of institutionalised monetary co-operation or in those associated with the harmonisation (although the preferred term at the time was 'co-ordination') of the separate foreign policies of the segments.

The core set of relations determining the management, political or otherwise, of Community business was captured by the concept of interdependence: 'a condition (of intensive economic exchange) which may influence political relationships but does not necessarily elicit an integrative response from those most affected.' ${ }^{125}$ Unlike 'conventional' neofunctionalist analysis, interdependence theory encapsulates the process of European integration in erratic rather than linear terms, emphasising 'the loss of control and sense of hopelessness which complex economic interactions can trigger, especially in governments whose fate turns on their ability to safeguard the welfare of their electorates'.126 In a way, it sets the limits of a federalist-inspired political union since it shifts the focus from questions of institution-building and constitutional engineering to those associated with the management of pressing realities as a response to the changing conditions of market forces and the economy.

The application of interdependence theory to integration studies in the 1970s produced less concern about the conceptualisation of the Community as a political system, or for that matter as a form of polity with clearly defined boundaries of institutional development. This, in turn, diverted attention from the oft-raised question of whether the Community should follow an intergovernmental or federalist path to institution-building, to questions dealing more directly with the implications of policy co-ordination for the efficiency of the system as a whole. Policy outputs, in other words, were seen as much more interesting clusters of analysis - at both micro and macro levels - as compared with 
abstract models of collective governance based on ideologically defined rules and procedures of large-scale political organisation. Institutionalisation thus became of secondary importance to the student of interdependence theory in the Community: governments may well achieve a considerable degree of policy co-ordination and cohesion without being represented in a highly institutionalised framework of interactions. In this sense, perhaps, by diminishing any deterministic projections of the larger configuration, interdependence theory deviates from neofunctionalist-driven analysis, let alone federal macropolitical aspirations. In Webb's words: 'Interdependence seems to be the answer for scholars and politicians who wish to keep their options open on the evolution of the EC.' ${ }^{127}$

On the other hand, there is a common denominator where interdependence analysts converge when referring to the internal dynamics of the Community system - that is, the practice of mutualism in the management of complex relations that results in a policy 'mix': a variety of costs and benefits to the participating (interdependent) units. In this view, interdependence theory may be able to explain some, albeit certainly not all, aspects of the various negotiating games being played at the European level between national governments, transnational actors and non-territorial central institutions. The emphasis here is on a perceived diffusion of decision-making power among the major actors, as well as on expected utilitarian outcomes of intense interrelationships on essentially nonconflict-prone areas. Areas, that is, where state and non-state (transnational) actors pursue their strategic choices in view of pressing socioeconomic problems stemming from functional, and to a lesser extent structural, interdependence. Hence 'transnational coalitions' take shape within the Community's multilayered setting, impinging with considerable rigour on its policy processes.

Moreover, by transcending the 'end product dilemma' of mainstream regional integration analysis - that is, federal state, confederation, union, and so on - interdependence theory claims to offer a pragmatic, ideologically free alternative to the study of both the structural conditions and policy outcomes of intensive interactions - something that supranationalism, the argument has it, by its nature cannot offer. To quote again from Webb: '[Interdependence] encourages the analyst to focus on the policy issues first and foremost rather than be diverted by the particular and frequently parochial institutional problems which infiltrate and obscure the policy debate in Brussels.' ${ }^{128}$

A fair amount of criticism directed against the interdependence school centres around the basic, and, it needs saying, hard-won, political properties of the Community system: the role and influence of its supranational institutions par excellence; the dynamics of institutional 'spillovers' or forward linkages leading to further institutionalisation; and the impact of 'extra-treaty' arrangements on the conditions of joint decision-making, especially when sensitive issues are at stake for a particular state or group of states. The list could well be extended to cover interinstitutional relations, bargaining practices promoting national interests, issues of large-scale jurisdictional competence, the constitutional 
implications of Community law for the domestic legal orders of states, and so on. These issues, often due to their controversial nature, are dealt with more explicitly by political theories of regional international integration.

But more importantly, perhaps, interdependence should be seen as only one side of the coin. The other is the principle and practice of autonomy on the part of national political authorities. The interplay between the two has produced, as many theorists rightly expected, a 'flexible equilibrium', or even 'multiple flexible equilibria', where structural (mainly systemic) properties were in a position to determine the quality of functions performed by state agents (ways of management), be they bureaucrats, administrators or government representatives. In a way, and this is not an attempt to simplify an inevitably complex reality based on open-ended processes (also capable of producing unintended consequences), the problem confronting the interdependence approach is that it relies primarily on horizontal interactions whose decisional outcomes, however - that is, the process of regulating a policy arena where co-operative action applies - are based on a set of authoritative rules reached by joint decisions but applied vertically to the domestic orders of the participating collectivities. A functionalist understanding of sovereignty, therefore, as part of the interdependence vocabulary, is in need of further clarification.

Ideally, in a system of highly interdependent relations, territorially demarcated boundaries become of secondary importance to the expected fruits (or non-costs) of concerted action. Yet it is often the case that the management and, more accurately, the exercise of managing these relations, rests closely with 'executive-centred elites' which are often willing to compromise the wider interest - as resulting from the dictates of interdependence itself - to avoid the danger of intersegmental confrontation. Here, consensual politics prevail, whether or not specific treaty provisions may require a different course of procedural (decisional) action. Interdependence, in other words, does not guarantee that rational decisions prevail between actors who find themselves in the middle of a difficult dilemma: to strengthen the co-operative ethos of the regional arrangements or to resort to autonomous action under ideological or party political pressures (in fact the latter may be part of a single political package, as has often been the case in the history of interstate bargaining within the Community).

What interdependence theory cannot properly address, then, is the question of explicitly political choices on the part of dominant governing elites about the nature and extent of their involvement in joint co-operative schemes. This is something with which, much to the detriment of supranationalist-driven aspirations about the Community's political future, state-centric approaches are better equipped to deal. In conclusion, interdependence theory places Community politics in a wider pluralist perspective of post-industrial relations, diverging attention from a structured analysis of hierarchical conceptions of the regional process to a much more diffused system of policy co-ordination, transnational coalition-formation and economic management. 


\section{Concordance systems}

More than thirty years have elapsed since Puchala's celebrated linking of the Community with the story of the elephant and the blind men. Although falling within the wider analytical framework of the interdependence school, Puchala's 'new thinking' about contemporary international integration is worth exploring in its own right, offering at the same time a thorough critical evaluation of conventional integration models. Indeed, in an attempt to break away from the classical theses of federalism and intergovernmentalism, Puchala discussed the integration phenomenon in terms of 'what it really is and is actually leading to. ${ }^{129}$ His main concern was that the pre-existing accounts of the relevant field, especially as applied in the case of Western Europe, had been characterised by conceptual confusion, stressing either the indispensability of national polities or that of the central institutions. As a result, normative theoretical preferences had exhausted the intellectual efforts of scholars, depriving the integration process of a descriptive model capable of conceptualising its distinctive properties and dynamics.

Puchala argued his case against the analytical validity of conventional approaches to the study of international integration such as federalism, functionalism, nationalism and what he called 'old-fashioned power-politics'. His criticism reflected the state of theorising integration in the early 1970s, a period when the Community's workings were characterised by a more favourable version of intergovernmentalism, but where no clear model of integration, or for that matter a wider conceptual consensus, had emerged among its students. Puchala was critical of the limited, predominantly economic, nature of the Community at that time, as well as of the autonomy of the Commission in representing the wider European interest being detached from the separate interests of the member states. His understanding of the Western European system also challenged the mainstream federalist approach, in that progress towards further integration was being equated with movement towards a central European government and the extent to which national political authorities had relinquished their sovereignty to an emerging federal state. The question he asked was 'to what extent does participation in an international integration arrangement actually enhance rather than undermine national sovereignty? ${ }^{130}$ This was something which effectively remained largely unspoken within the federalist camp.

However, Puchala was also critical of the view that equates international integration with nation-building processes. The point he made here was that Western European integration does not even closely approximate a model of political evolution where the measurement of its 'progress' or 'success' is conditioned by the extent to which the component parts that are being integrated move towards 'the social and cultural assimilation of [their] nationalities. ${ }^{131}$ In this respect, Puchala was particularly sceptical of the applicability of the 'nationalism model' in the study of international integration. His main argument was that such an approach lacked evidence of progress towards the envisaged process 
of assimilation among diverse peoples. Again, students applying the 'nationalism model' were asking, according to Puchala, the wrong questions: 'about people-to-people interactions and transactions, about similarities and differences in people's life styles, value systems and cultural norms, and especially about their attitudes toward one or another and attendant perceptions of "weness". ${ }^{132}$ In his view, the rather more interesting question to pose was about the relationship between peoples and their national governments, as well as between the former and international organisations and processes.

In his equally critical approach to Mitrany's functionalism, Puchala questioned the extent to which his sectoral approach, for all its validity in locating the sources of international co-operation and the role of transnational (nongovernmental) actors, had actually worked in the way in which the functionalist model originally intended. The point he made here was that in internationally integrating systems, '[1]eadership, initiative and prerogative have by and large remained with national governments, ${ }^{133}$ rather than with newly formed technocratic agencies, large-scale bureaucratic entities and non-governmental actors. Moreover, functionalist theorising failed to predict the importance attached by national governments to pursuing 'welfare' objectives, rather than merely 'power' relations at the regional level. Equally, Puchala dismissed the functionalist claim about non-political aspects of international co-operation, arguing that no such issues really exist in interstate relations. He also pointed to another deficiency of the functionalist design in that, instead of being primarily preoccupied with sector-to-sector task expansion, 'there is possible expansion in the political system brought into being when functional sectors are integrated internationally. ${ }^{134}$ Finally, he was concerned with the normative/hypothetical aspects of the functionalist analysis in that the end product of international integration would resemble a 'functional federation' or some sort of 'multi-sector merger'. In brief, functionalism in the Mitranian tradition failed, in Puchala's view, to ask 'how international co-operation is in fact achieved during international integration in the very course of international politics. ${ }^{135}$ It has been 'partially straitjacketed' by its own integrative assumptions.

Last in his 'critical list' comes the realist school of thought, perceiving international integration as 'power politics'. This traditional international relations approach fails to understand what the phenomenon is all about, not least because it views international integration as 'a process of mutual exploitation wherein governments attempt to mobilise and accumulate the resources of neighbouring states in the interests of enhancing their own power. ${ }^{136}$ Such an account emphasises the self-interestedness of national governing elites which perceive international integration as an instrument towards the accumulation of greater power as 'international marriages of convenience, comfortable for all partners as long as self-interests are satisfied. ${ }^{137}$ The point that realist thinking is making is that international integration never really gets 'beyond the nationstate'. It stays confined within the dictates of international diplomacy, leading eventually towards disintegration: the participating actors are 'destined for 
divorce the moment any partner's interests are seriously frustrated. ${ }^{138}$ In general terms, Puchala noted, political realists are so convinced that international integration is played by traditional international relations rules - also set by traditional actors - that they never ask 'whether actors committed to international integration may be pursuing any other than the traditional inventory of international goals - autonomy, military security, influence and prestige. ${ }^{139}$ In brief, 'by assuming that international politics remains the same "old game" and that international integration is but a part of it, ${ }^{140}$ the advocates of the realist analysis fail to take into account the possibility, if not reality, that international integration arrangements may in the end define the self-interests of states themselves, rather than vice versa.

So, with what did Puchala propose to replace the existing deficiencies in international integration analysis? His answer was that 'contemporary international integration can best be thought of as a set of processes that produce and sustain a Concordance System at the international level'. ${ }^{141}$ Such a system of 'co-operatively interacting states' is based on the harmonisation of the actors' interests and on mutually beneficial interactions. The role of the nation-state remains central in the integration process but at the same time the institutions of the larger system possess their own organisational and operational logic. A Concordance System may include actors from different organisational levels or governmental arenas without producing a system of hierarchical authority structures. Rather, 'each of the actors remain[s] semiautonomous ... all are interdependent, and all interact in pursuit of consensus that yields mutual rewards'. ${ }^{142}$ It is a complex international pluralist system with high levels of institutionalisation and various organisational networks, where international interactions are mainly channelled through bureaucratic, rather than diplomatic, means: 'a system of relations among sovereign states and separate peoples. ${ }^{143}$

In the Concordance System, problem-solving and conflict regulation are facilitated via institutionalised, constitutional, precedential or otherwise standardised, patterned procedures which all actors commit themselves to use and respect. ${ }^{34}$ But it is not a state, national or transnational in kind. Rather, it takes the form of numerous functionally specific bodies, without having to rely upon federalist-inspired processes of institutional centralisation. More importantly, political conflict arises from different approaches to international co-operation, mainly in terms of the necessary procedural avenues to be pursued, rather than from 'fundamental incompatibilities in the interests of the various actors. ${ }^{145}$ Hence conflict may well be one of the system's functional aspects and not, as is often the case in various realist predictions, a move towards disintegration (or de-federation). Another important dimension of a Concordance System is the bargaining techniques used by the relevant actors to reach mutually reinforcing outcomes in international negotiations: coercion and confrontation should be excluded from the acceptable patterns of international (intrasystemic) behaviour. On the contrary, the rules of the system are determined by 
what Puchala calls a 'full information' game, where secrecy and deception are altogether unknown.

International interdependence - often seen as a result of 'national inadequacy' - emerges as a defining property of Concordance Systems. This does not amount, however, to a negation of the nation-state. Rather, 'nation-states can be preserved as distinct entities only through the international pooling of resources to confront problems that challenge their separate existence. ${ }^{146}$ Likewise, Puchala explicitly states that 'mass populations within the Concordance System need not be assimilated into a supranationality. ${ }^{147}$ However, they do confer legitimacy upon the system, comply with its authoritative decisional outcomes and, in general, support the integrative process.

In summary, the theoretical lenses employed by the Concordance Systems approach capture aspects of the structural, attitudinal and procedural conditions of international integration, while freeing the analyst from normative, hypothetical and ideologically defined interpretations of the integrative phenomenon. Thus it is a pragmatic approach aiming to reveal the underlying structure of relations between highly interdependent units and the way in which large-scale co-ordination projects, patterned on routinised procedures and standardised codes of conduct, transcend the ill-effects of adversarial politics in multiple policy arenas. It is these regime aspects of the Concordance System which are mainly responsible for the elimination of competitive tussles for political authority among the participants and the prevalence of positive-sum outcomes in multilateral negotiations. In conclusion, Puchala's approach to international integration attempted a fresh start by exploring the possibilities of consensusformation, pragmatic politics, patterned procedures, institutionalised compromise, mutual responsiveness and co-operative behaviour. It is our contention that his analysis remains a valuable contribution in the field.

\section{A final note}

Having examined the core theories of integration both during the formative years of the regional process and throughout the 1970s, we can now turn to the relationship between the major constitutional revisions of the original treaties and the theoretical implications stemming from them, especially in the light of new approaches to the study of European integration in the 1990s, especially from the perspective of EU polity-building. Such an analysis will help us link the theoretical findings of Chapter 2 with the more detailed examination of recent treaty reforms, as epitomised in the Amsterdam and Nice outcomes, respectively (Chapters 3 and 4 ). It will also provide the analytical framework and normative basis from which we may develop a more penetrating understanding of the evolutionary nature of the integration process in general, and the qualitative transformation of the regional system from a policyoriented enterprise to a transnational polity: a system of governance capable of 
producing authoritative political decisions, allocating values in European society, and transforming the traditional patterns of interaction among the component state/citizen parts.

\section{Notes}

1 Donald J. Puchala, 'The Integration Theorists and the Study of International Relations', in C. W. Kegley and E. Wittkopf (eds), The Global Agenda: Issues and Perspectives, New York: Random House, 1984, p. 198.

2 Paul Taylor, International Co-operation Today: The European and the Universal Patterns, London: Elek Books, 1971, p. i.

3 Robert O. Keohane and Stanley Hoffmann, 'Conclusions', in William Wallace (ed.), The Dynamics of European Integration, London: Royal Institute of International Affairs, 1990, p. 284.

4 Clive H. Church, European Integration Theory in the 1990s, European Dossier Series, No. 33, University of North London, 1996, p. 8.

5 Ibid.

6 Taylor, International Co-operation, p. 149.

7 Donald J. Puchala, 'Of Blind Men, Elephants and International Integration', Journal of Common Market Studies, December 1972, pp. 267-84.

8 For definitions of the terms see Murray Forsyth, Unions of States: The Theory and Practice of Confederation, Leicester: Leicester University Press, 1981, pp. 1-16.

9 Alberta M. Sbragia, 'Thinking about the European Future', in Alberta M. Sbragia (ed.), Euro-Politics, Washington, DC: The Brookings Institution, 1992, pp. 13, 257.

10 Thomas Christiansen, 'European Integration Between Political Science and International Relations Theory: The End of Sovereignty?', EUI Working Paper, No. 94/4, San Domenico: Badia Fiesolana, FI, 1994, p. 10.

11 On the distinction between these concepts see Forsyth, Unions of States, pp. 10-16.

12 Dimitris N. Chryssochoou, 'New Challenges to the Study of European Integration: Implications for Theory-Building', Journal of Common Market Studies, December 1998, pp. 521-42. See also Dimitris N. Chryssochoou, Democracy in the European Union, London and New York: I. B. Tauris, 1998.

13 William Wallace, 'Theory and Practice in European Integration', in Simon Bulmer and Andrew Scott (eds), Economic and Political Integration in Europe: Internal Dynamics and Global Context, Oxford: Basil Blackwell, 1994, p. 274. Likewise, Adonis has observed: 'It is fashionable to talk of a "democratic deficit", but that is but one aspect of a more chronic malaise: constitutional chaos.' See Andrew Adonis, 'Subsidiarity: Myth, Reality and the Community's Future', House of Lords Select Committee on the European Communities, London, June 1990, p. 11.

14 Wallace, 'Theory and Practice', pp. 274, 275.

15 Alberta M. Sbragia, 'The European Community: A Balancing Act', Publius, Summer 1993, p. 24.

16 See, respectively, Emil J. Kirchner, Decision Making in the European Community, Manchester: Manchester University Press, 1992, pp. 10-14; Simon Bulmer and Wolfgang Wessels, The European Council: Decision-Making in European Politics, London: Macmillan, 1988, pp. 8-11; and Paul Taylor, International Organization in the Modern World: The Regional and the Global Process, London: Pinter, 1993, pp. 80-111.

17 David McKay, 'On the Origins of Political Unions', paper presented at the 2nd ECSAWorld Conference, 'Federalism, Subsidiarity and Democracy in the European Union', Brussels, 4-6 May 1994, p. 6. 
18 Andrew Moravcsik, 'Preferences and Power in the European Community: A Liberal Intergovernmentalist Approach', Journal of Common Market Studies, December 1993, p. 507.

19 Quoted in C. Webb, 'Theoretical Perspectives and Problems', in Helen Wallace et al. (eds), Policy-Making in the European Community, Chichester: John Wiley, 1983, pp. 36, 40, n. 22.

20 William Wallace, 'Less than a Federation, More than a Regime: The Community as a Political System', in Wallace et al. (eds), Policy-Making, p. 410.

21 Quoted in ibid., p. 406.

22 Quoted in George Tsembelis, 'The Power of the European Parliament as a Conditional Agenda-Setter', American Political Science Review, March 1992, p. 128.

23 Keohane and Hoffmann, 'Conclusions', p. 282.

24 Fritz W. Scharpf, 'The Joint-Decision Trap: Lessons from German Federalism and European Integration', Public Administration, Autumn 1988, p. 265.

25 Ibid., pp. 257, 242. Cf. William Wallace, 'Europe as a Confederation: The Community and the Nation-State', Journal of Common Market Studies, September-December 1982, p. 67; Paul Taylor, 'Interdependence and Autonomy in the European Communities: The Case of the European Monetary System', Journal of Common Market Studies, June 1980, p. 373; and Stanley Hoffmann, 'Obstinate or Obsolete? The Fate of the Nation State in Western Europe', Daedalus, Summer 1966, p. 910.

26 A. J. R. Groom, 'The European Community: Building Up, Building Down, and Building Across', in Conference Proceedings, People's Rights and European Structures, Manresa, September 1993, p. 47.

27 David Mitrany, A Working Peace System, London: Royal Institute of International Affairs, 1943, pp. 72-3.

28 Paul Taylor, 'The Concept of Community and the European Integration Process', Journal of Common Market Studies, December 1968, p. 86.

29 David Mitrany, The Functional Theory of Politics, London: Martin Robertson, 1976, p. 119. Others, like Hirst, are partly in favour of these views, in so far as 'different forms of representation are not seen as a substitute for representative democracy, but rather as a supplement to it'. See Paul Hirst, Associative Democracy: New Forms of Economic and Social Governance, Cambridge: Polity, 1994, pp. 16-17.

30 Ibid., p. 261.

31 Uwe Kitzinger, 'Time-Lags in Political Psychology', in James Barber and Bruce Reeds (eds), European Community: Vision and Reality, London: Croom Helm, 1973, p. 13.

32 Ibid.

33 This point is analysed further in Paul Taylor, 'Functionalism: The Approach of David Mitrany', in A. J. R. Groom and Paul Taylor (eds), Frameworks for International Cooperation, London: Pinter, 1990, p. 132.

34 Ibid.

35 Quoted in A. Bosco, 'What is Federalism?', paper presented at the 2nd ECSA-World Conference, 'Federalism, Subsidiarity and Democracy in the European Union', Brussels, 4-6 May 1994, p. 15.

36 R. L. Watts, 'Federalism, Regionalism, and Political Integration', in David M. Cameron (ed.), Regionalism and Supranationalism: Challenges and Alternatives to the Nation-State in Canada and Europe, London: The Institute for Research on Public Polity, 1981, p. 10.

37 Ibid., p. 13.

38 Murray Forsyth, Political Science, Federalism and Europe, Discussion Papers in Federal Studies, No. FS95/2, University of Leicester, 1995, p. 12.

39 K. Robinson, 'Sixty Years of Federation in Australia', Geographical Review, 51:1, 1961, p. 2. Quoted in A. Murphy, 'Belgium's Regional Divergence: Along the Road to Federation', in Graham Smith (ed.), Federalism: The Multiethnic Challenge, London and New York: Longman, 1995, p. 75. 
40 Preston King, 'Federation and Representation', in Michael Burgess and A.-G. Gagnon (eds), Comparative Federalism and Federation, New York: Harvester Wheatsheaf, 1993, pp. 95-6. Cf. Preston King, Federalism and Federation, London: Croom Helm, 1982, pp. $88-95$.

41 Ibid., p. 96.

42 Daniel J. Elazar, Exploring Federalism, Tuscaloosa: The University of Alabama Press, 1987, pp. 108-9.

43 King, 'Federation and Representation', p. 96.

44 Watts, 'Federalism', pp. 13-14.

45 Carl J. Friedrich, Trends of Federalism in Theory and Practice, London: Pall Mall Press, 1968, p. 3.

46 Reginald J. Harrison, Europe in Question: Theories of Regional International Integration, London: Allen \& Unwin, 1974, p. 43.

47 Michael Burgess, 'Federalism as Political Ideology: Interests, Benefits and Beneficiaries in Federalism and Federation', in Burgess and Gagnon (eds), Comparative Federalism, p. 149.

48 On this issue see Dimitris N. Chryssochoou, 'Federalism and Democracy Reconsidered', Regional and Federal Studies, Summer 1998, pp. 1-20.

49 Robert R. Bowie, 'The Process of Federating Europe', in A. W. Macmahon (ed.), Federalism: Mature and Emergent, New York: Garden City, 1987, p. 497.

50 Ibid., p. 496. For an account of past attempts to unite the Continent, see Sydney D. Bailey, United Europe: A Short History of the Idea, London: National News-Letter, 1948.

51 Ibid., p. 497. Bowie writes: 'As important as [the nation-state's] economic and political decline was the spiritual malaise that affected much of its population.' See ibid., p. 495.

52 Harrison, Europe in Question, p. 45.

53 As quoted in Uwe Kitzinger, The European Common Market and Community, London: Routledge, 1967, pp. 29-33.

54 Kitzinger, 'Time-Lags in Political Psychology', p. 8.

55 Andrea Bosco, 'The Federalist Project and Resistance in Continental Europe', in Andrea Bosco (ed.), The Federal Idea: The History of Federalism Since 1945, Vol. II, London and New York: Lothian Foundation Press, 1992, p. 52. See also Altiero Spinelli and Ernesto Rossi, Il Manifesto di Ventotene, Pavia, 1944, pp. 19-20. Cf. Mario Albertini, 'The Ventotene Manifesto: The Only Road to Follow', in Lucio Levi (ed.), Altiero Spinelli and Federalism in Europe and in the World, Milan: FrancoAngeli, 1990, pp. 127-40.

56 Altiero Spinelli and Ernesto Rossi, 'European Union in the Resistance', Government and Opposition, April-July 1967, pp. 321-9. Quoted in Ghita Ionescu (ed.), The New Politics of European Integration, London: Macmillan, 1972, p. 2.

57 Gordon Smith, 'The Crisis of the West European State', in Cameron (ed.), Regionalism and Supranationalism, p. 25.

58 Lucio Levi, 'Altiero Spinelli, Mario Albertini and the Italian Federalist School: Federalism as Ideology', in Bosco (ed.), The Federal Idea, II, p. 214.

59 Lucio Levi, 'Recent Developments in Federalist Theory', in Levi (ed.), Altiero Spinelli, p. 62. Cf. Watts, 'Federalism', p. 4.

60 John Pinder, 'The New European Federalism', in Burgess and Gagnon (eds), Comparative Federalism, p. 45.

61 Sergio Pistone, 'Altiero Spinelli and a Strategy for the United States of Europe', in Andrea Bosco (ed.), The Federal Idea: The History of Federalism from the Enlightenment to 1945, Vol. I, London and New York: Lothian Foundation Press, 1991, pp. 351-7. See also Michael Burgess, 'Federal Ideas in the European Community: Altiero Spinelli and European Union', Government and Opposition, Summer 1984, pp. 339-47.

62 Bosco, 'What is Federalism?', p. 2.

63 Denis De Rougemont, 'The Campaign of European Congresses', in Ghita Ionescu (ed.), The New Politics of European Integration, London: Macmillan, 1972, p. 25. 
64 Harrison, Europe in Question, p. 48.

65 Ibid.

66 Max Beloff, writing in The Times, asserted that 'what one is struck with is not the parallel . . but the immensity of the difference'. He concluded: 'those who believe in furthering European unity must seek elsewhere than in American federalism.' See Max Beloff, 'False Analogies from Federal Example of the United States', The Times, 4 May 1950. Cf. Roderick MacFarquhar, 'The Community, the Nation-State and the Regions', in Bernard Burrows et al. (eds), Federal Solutions to European Issues, London: Macmillan, 1978, pp. 17-24.

67 Quoted in Bosco, 'What is Federalism?', p. 13.

68 Forsyth, Unions of States, pp. 1-16.

69 B. M. Sharma and L. P. Choudhry, Federal Polity, London: Asia Publishing House, 1967, pp. 11-12. Cf. Paul Taylor, The Limits of European Integration, New York: Columbia University Press, 1983, pp. 270-5. Likewise, Watts has pointed out: 'The difference between the federal and confederal forms lies in the fact that in federal systems, the central institutions are free to exercise responsibilities assigned to them under the constitution in a direct relationship with the electorate, while in confederal systems the central agencies, operating as delegates of the regional governments, are dependent upon them for agreement to common policies.' See Watts, 'Federalism', p. 12.

70 Forsyth, Political Science, p. 16.

71 Robert A. Dahl, A Preface to Democratic Theory, Chicago: University of Chicago Press, 1956, p. 38.

72 Forsyth, Unions of States, pp. 15-16.

73 Murray Forsyth, 'Towards a New Concept of Confederation', European Commission for Democracy Through Law, Council of Europe, 1994, p. 12.

74 Forsyth, Unions of States, p. 1.

75 Daniel J. Elazar et al., Federal Systems of the World: A Handbook of Federal, Confederal and Autonomy Arrangements, 2nd edn, London: Longman Current Affairs, 1994, p. xvi. The author defines the federation as 'a compound polity compounded of strong constituent entities and a strong general government, each possessing powers delegated to it by the people and empowered to deal directly with the citizenry in the exercise of those powers'.

76 Forsyth, Unions of States, pp. 11, 15-16.

77 Ibid., p. 16.

78 Ibid., p. 15.

79 Heinrich von Treitschke, 'State Confederations and Federated States', Book III, in Murray Forsyth et al. (eds), The Theory of International Relations, London: Allen \& Unwin, 1970, pp. 330, 331.

80 Forsyth, Unions of States, p. 13.

81 Ibid., pp. 13-14.

82 On this idea see Anthony D. Smith, National Identity, Harmondsworth: Penguin Books, 1991, p. 153.

83 Forsyth, Unions of States, p. 15.

84 Ibid. and p. 205.

85 Friedrich, Trends of Federalism, pp. 11-12. Friedrich defines federation as 'a union of groups, united by one or more common objectives, rooted in common values, interests, or beliefs, but retaining their distinctive group character for other purposes'. See p. 177.

86 Murray Forsyth, 'Federalism and Confederalism', in Chris Bacon (ed.), Political Restructuring in Europe: Ethical Perspectives, London and New York: Routledge, 1994, p. 58.

87 Friedrich, Trends of Federalism, p. 82.

88 Forsyth, 'Federalism and Confederalism', pp. 57-8. 
89 Keohane and Hoffmann, 'Conclusions', p. 279.

90 See, respectively, Christopher Brewin, 'The European Community: A Union of States without Unity of Government', Journal of Common Market Studies, 26:1, 1987, pp. 1-24; Clive H. Church, 'The Not so Model Republic? The Relevance of Swiss Federalism to the European Community', Leicester University Discussion Papers in Federal Studies, No. FS93/4, November 1994, p. 15; and Elazar et al., Federal Systems, p. xvi.

91 Karl W. Deutsch, Political Community and the North Atlantic Area, Princeton: Princeton University Press, 1957, p. 5.

92 Paul Taylor, 'A Conceptual Typology of International Organisation', in Groom and Taylor (eds), Frameworks, p. 18.

93 See Ferdinand Tönnies, Community and Association, translated and supplemented by Charles P. Loomis, London: Routledge \& Kegan Paul, 1974.

94 Chantal Mouffe, The Return of the Political, London: Verso, 1993, p. 61.

95 Eugene Kamenka, Bureaucracy, Oxford: Basil Blackwell, 1989, p. 81.

96 Taylor, The Limits of European Integration, p. 3.

97 Tönnies, Community and Association, p. 160. Cf. R. M. MacIver, Community: A Sociological Study, London: Macmillan, 1936, pp. 22-8. MacIver states: 'A community is a focus of social life; an association is an organisation of social life ... but community is something wider and freer than even the greatest associations.' See p. 24.

98 Tönnies, Community and Association, pp. 38-9.

99 Kamenka, Bureaucracy, p. 79.

100 On the relationship between Gemeinschaft and authority see Raymond Plant, Community and Ideology: An Essay in Applied Social Philosophy, London and Boston: Routledge \& Kegan Paul, 1974, pp. 51-8.

101 Taylor, International Co-operation, p. 7.

102 Ibid., p. 10.

103 Ernst B. Haas, The Uniting of Europe: Political, Social and Economic Forces 1950-1957, London: Stevens \& Sons, 1958.

104 Alan S. Milward and Viebeke Sørensen, 'Independence or Integration? A National Choice', in Alan S. Milward et al. (eds), The Frontier of National Sovereignty: History and Theory 1945-1992, London and New York: Routledge, 1993, p. 3.

105 David Mutimer, 'Theories of Political Integration', in Hans J. Michelmann and Panayotis Soldatos (eds), European Integration: Theories and Approaches, Lanham: University Press of America, 1994, p. 33.

106 The term 'political community' is used here in accordance with Haas' definition, that is, as 'a condition in which specific groups and individuals show more loyalty to their central political institutions than to any other political authority'. See Haas, The Uniting of Europe, p. 5.

107 Reginald Harrison, 'Neo-functionalism', in Groom and Taylor (eds), Frameworks, p. 145.

108 Taylor, The Limits of European Integration, p. 7.

109 Ernst B. Haas, Beyond the Nation-State: Functionalism and International Organization, Stanford: Stanford University Press, 1964, p. 35. Quoted in Taylor, 'The Concept of Community', p. 87.

110 Taylor, 'The Concept of Community', p. 87.

111 Ernst B. Haas, The Obsolescence of Regional Integration Theory, Berkeley, CA: Institute of International Studies, 1975.

112 Church, European Integration Theory, p. 20.

113 Ibid.

114 Taylor, International Organization, p. 3.

115 Robert Jervis, 'Security Regimes', in Stephen D. Krasner (ed.), International Regimes, Ithaca: Cornell University Press, 1983, p. 173.

116 Robert W. Cox, 'Social Forces, States and World Orders: Beyond International Relations 
Theory', Millennium, 10:2, Summer 1981, p. 128. Quoted in Groom and Taylor (eds), Frameworks, p. 202.

117 Stephen D. Krasner, 'Structural Causes and Regime Consequences: Regimes as Intervening Variables', in Krasner (ed.), International Regimes, p. 2.

118 Oran Young, International Cooperation: Building Regimes for Natural Resources and the Environment, Ithaca: Cornell University Press, 1989, p. 12. Quoted in Robert E. Breckinridge, 'Reassessing Regimes: The International Regime Aspects of the European Union', Journal of Common Market Studies, June 1997, p. 179.

119 Ibid., p. 16.

120 Krasner, 'Structural Causes', p. 2.

121 Scharpf, 'The Joint-Decision Trap'.

122 Breckinridge, 'Reassessing Regimes', pp. 181-3.

123 Ibid., p. 183.

124 Wallace, 'Less than a Federation', p. 408.

125 Webb, 'Theoretical Perspectives', p. 32.

126 Ibid.

127 Ibid., p. 33.

128 Ibid., p. 34.

129 Puchala, 'Of Blind Men', p. 268.

130 Ibid., p. 271.

131 Ibid.

132 Ibid., p. 272.

133 Ibid., p. 273.

134 Ibid., p. 274.

135 Ibid., p. 275.

136 Ibid.

137 Ibid., p. 276.

138 Ibid.

139 Ibid.

140 Ibid.

141 Ibid., p. 277.

142 Ibid., p. 278.

143 Ibid.

144 Ibid., p. 279.

145 Ibid., p. 280.

146 Ibid., p. 282.

147 Ibid., p. 283. 